\title{
A role for acidophilic granulocytes in the testis of the gilthead seabream (Sparus aurata L., Teleostei)
}

\author{
E Chaves-Pozo, P Pelegrín, V Mulero, J Meseguer and A García Ayala \\ Department of Cell Biology, Faculty of Biology, University of Murcia, Campus Universitario de Espinardo, 30100 Murcia, Spain \\ (Requests for offprints should be addressed to A García Ayala; Email: agayala@um.es)
}

\begin{abstract}
In mammals, a complex interaction between the immune and the reproductive systems has been described, in which testicular immune cells produce cytokines and growth factors which modulate gonad functions, while specific gonad cells influence the immune response in this organ. In this study we describe the presence of acidophilic granulocytes in the testis of the hermaphrodite teleost fish gilthead seabream (Sparus aurata L.) by using a specific monoclonal antibody. During the post-spawning stage of the testis, this cell type appears in the germinal compartment, accumulates interleukin (IL) $-1 \beta$ and does not seem
\end{abstract}

to be involved in the phagocytosis of degenerating cells. Moreover, in vitro, 11-ketotestosterone and $17 \beta$-oestradiol, the principal fish sexual steroids, regulate the respiratory burst activity of acidophilic granulocytes obtained from the head-kidney (the bone marrow equivalent in fish) and the intracellular accumulation of IL-1 $\beta$ by these cells. It is likely, therefore, that IL-1 $\beta$ produced by testicular acidophilic granulocytes regulates important functions of the testis in fish.

Journal of Endocrinology (2003) 179, 165-174

\section{Introduction}

The interaction between the immune and the reproductive systems has been relatively well studied in mammals. Recently, it has been suggested that the cytokines produced by testicular leucocytes are able to act as growth factors and regulators of important functions of the gonads. Cytokines, such as interleukin (IL)-1, IL-3, IL-6, tumour necrosis factor- $\alpha$ (TNF- $\alpha$ ), interferon- $\gamma$ (INF- $\gamma$ ), colonystimulating factor-1 (CSF-1) and granulocyte-macrophage CSF (GM-CSF), have been related to the growth and development of follicles, ovulation, luteal development, spermatogenesis and steroidogenesis (Hunt \& Johnson 1999, Robertson 1999, Tuo et al. 1999, Hedger \& Meinhardt 2003). However, little has been published about these interactions in fish, although it has recently been suggested that murine recombinant IL-1 $\beta$ and TNF- $\alpha$ modify steroid hormone production by Leydig cells in goldfish (Lister \& Van der Kraak 2002).

The gilthead seabream (Sparus aurata L.) is a seasonal breeding, protandrous hermaphrodite teleost fish. The specimens are male during the first two years with a tubular testis that shows asynchronous spermatogenesis, although some specimens might have some previtelogenic ovocytes during their male phase (D'Ancona 1941, Pasquali 1941). The spawning period of gilthead seabream males takes place at the end of autumn (November-December) (Lasserre 1972). Afterwards, dur- ing the post-spawning period/beginning of the resting period (January-March), the gonads undergo a degenerative process in which testicular organization is disrupted. During this stage most germ cells, epithelial cells and fibroblasts are vacuolated and several immune cell types are seen inside the testis (Bruslé-Sicard \& Fourcault 1997). The phagocytosis of these degenerating cells by Sertoli cells and macrophages has been observed by light and electron microscopy in a few fish species. These studies have also suggested that granulocytes might be involved in this process (Lahnsteiner \& Patzner 1990, Besseau \& Faliex 1994, Loir et al. 1995, Lone et al. 2001). However, the precise roles of these leucocytes in the testis are unknown.

In the present study, we unequivocally demonstrate the presence of acidophilic granulocytes in the germinal compartment in the post-spawning stage of the testis of gilthead seabream using a specific monoclonal antibody to this cell type (G7) (Sepulcre et al. 2002). Moreover, we show for the first time that these cells accumulate IL-1 $\beta$ in the testis, suggesting that this cytokine plays a role in regulating important functions of this organ. Our in vitro studies also demonstrate that 11-ketotestosterone (11-KT) and $17 \beta$-oestradiol $\left(\mathrm{E}_{2}\right)$, the main sexual steroids in fish, are not able to induce the intracellular accumulation of IL-1 $\beta$ in acidophilic granulocytes obtained from the headkidney (the bone marrow equivalent in fish), but rather they modulate IL-1 $\beta$ accumulation in these cells upon activation by immunological stimuli. 


\section{Materials and Methods}

Fish

Healthy specimens of mature male gilthead seabream, with body weights (bw) of 100-200 g were obtained in September 2001 from CULMAREX S.A. (Murcia, Spain). The fish had been kept in a 2601 running-seawater aquaria (flow rate $1500 \mathrm{l} / \mathrm{h}$ ) at $20^{\circ} \mathrm{C}$ with a $12 \mathrm{~h}$ light/ $12 \mathrm{~h}$ darkness cycle, and fed with a commercial pellet diet (ProAqua, Palencia, Spain) at a feeding rate of $15 \mathrm{~g}$ dry diet $/ \mathrm{kg}$ biomass of fish per day. Sampling was carried out from December (2001) to April (2002). Specimens were decapitated and the gonads and the head-kidneys were removed. Gonads were processed for light and electron microscopy and head-kidneys for cell culture. Some specimens were intraperitoneally injected with $50 \mathrm{mg} / \mathrm{kg}$ bw bromodeoxyuridine (BrdU) and, after $2 \mathrm{~h}$, the testes were removed and processed for light microscopy. The studies presented in this manuscript were approved by the Bioethical Committee of the University of Murcia.

\section{Light microscopy and immunohistochemical staining}

The gonads were fixed in Bouin-Hollande fluid or 4\% paraformaldehyde solution, embedded in Paraplast Plus (Sherwood Medical, Athy, Ireland) and sectioned at $5 \mu \mathrm{m}$. After dewaxing and rehydration, the sections were subjected to the peroxidase-antiperoxidase (PAP) technique or to an indirect immunocytochemical method (Sternberger 1986). Some sections were stained with haematoxylin-eosin.

Serial sections were incubated for $40 \mathrm{~min}$ in peroxidase quenching solution $\left(\mathrm{H}_{2} \mathrm{O}_{2}\right.$ in methanol, 1:9) to eliminate the endogenous peroxidase. The sections were then rinsed in Coons buffer $(0 \cdot 01 \mathrm{M}$ sodium diethylbarbiturate, $0 \cdot 1 \mathrm{M}$ $\mathrm{NaCl}, \mathrm{pH} 7 \cdot 4$ ) and in Coons buffer containing 0.01\% BSA and $0 \cdot 2 \%$ Triton X-100 (CBT). After 30-min incubation with skimmed milk powder in Coons buffer to block the nonspecific reaction, they were rinsed in CBT and incubated for $2 \mathrm{~h}$ at room temperature with a monoclonal antibody specific to gilthead seabream acidophilic granulocytes (G7) (Sepulcre et al. 2002) or with a rabbit polyclonal antiserum to gilthead seabream (sb) IL-1 $\beta$ (anti-sbIL-1 $\beta$ ) (Pelegrín et al., 2004), at the optimal dilution of $1: 10$ or $1: 100$ respectively. After washing in CBT, the sections that had been incubated with antisbIL-1 $\beta$ were exposed to swine anti-rabbit $\operatorname{IgG}$ (Dako A/S, Glostrup, Denmark) diluted 1:20 with CBT for $1 \mathrm{~h}$ at room temperature, washed with $\mathrm{CBT}$, and incubated with rabbit PAP complex (Dako A/S) diluted 1:100 with $\mathrm{CBT}$ for $1 \mathrm{~h}$ at room temperature. Sections that had been incubated with G7 were exposed to anti-mouse IgG (whole molecule) peroxidase conjugate (Sigma, Madrid, Spain) diluted 1:100 for $1 \mathrm{~h}$ at room temperature. The sections were then washed in CBT and in $0.5 \mathrm{M}$ Tris-

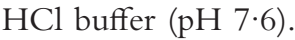

The peroxidase activity for all the immunoreactions was revealed by incubation with $0 \cdot 05 \% 3,3^{\prime}$-diaminobenzidine tetrahydrochloride (DAB) in Tris- $\mathrm{HCl}$ buffer $(\mathrm{pH} 7 \cdot 6)$ containing $0.05 \% \mathrm{H}_{2} \mathrm{O}_{2}$ for $15 \mathrm{~min}$ at room temperature. The sections were slightly counterstained with haematoxylin. The specificity of the reactions was determined by omitting the first antiserum.

The gonad sections from BrdU-treated specimens were incubated in peroxidase quenching solution for $40 \mathrm{~min}$, in $1 \%$ periodic acid at $60{ }^{\circ} \mathrm{C}$ for $30 \mathrm{~min}$ and in $0.5 \%$ skimmed milk powder in PBS for 30 min. Afterwards, they were incubated with a monoclonal antibody anti-BrdU (Becton Dickinson, San Jose, CA, USA) at the optimal dilution of 1:100 in PBS for $2 \mathrm{~h}$ at room temperature. Subsequently, sections were washed in PBS, incubated with anti-mouse $\operatorname{IgG}$ (whole molecule) peroxidase conjugate for $1 \mathrm{~h}$ at room temperature, and the reaction was revealed by incubation with $\mathrm{DAB}$, as described previously.

\section{Electron microscopy}

Samples were fixed in $1 \%$ glutaraldehyde in $0.1 \mathrm{M}$ cacodylate buffer $\left(\mathrm{pH} \mathrm{7.2)}\right.$ for $2 \mathrm{~h}$ at $4{ }^{\circ} \mathrm{C}$, then postfixed in $1 \%$ osmium tetroxide in $0.1 \mathrm{M}$ cacodylate buffer $(\mathrm{pH}$ 7.2) for $1 \mathrm{~h}$ at $4{ }^{\circ} \mathrm{C}$ and embedded in Epon. Ultrathin sections were obtained with a Reichert-Jung ultramicrotome, contrasted with uranyl acetate and lead citrate and examined with a Zeiss EM 10C electron microscope.

\section{Cell culture and treatments}

The head-kidneys were washed in sRPMI medium (RPMI-1640 culture medium (Gibco, Barcelona, Spain) adjusted to gilthead seabream serum osmolarity (353.33 mosmol) with $0.35 \% \mathrm{NaCl}$ ) supplemented with 100 units $/ \mathrm{ml}$ penicillin and $100 \mu \mathrm{g} / \mathrm{ml}$ streptomycin $(\mathrm{P} / \mathrm{S}$, Biochrom, Berlin, Germany). Cell suspensions were obtained by forcing fragments of the organ through a nylon mesh (mesh size $100 \mu \mathrm{m}$ ) and aliquots of $5 \times 10^{6}$ cells were incubated in $100 \mu \mathrm{l}$ sRPMI containing 1\% free steroid synthetic serum (Serum Replacement 2, Sigma), in the presence of $0,0 \cdot 1,0 \cdot 5,1$ or $5 \mathrm{ng} / \mathrm{ml} 11-\mathrm{KT}$ or $\mathrm{E}_{2}$ for 8,22 and $46 \mathrm{~h}$. In some experiments, cells were also stimulated overnight with $1 \mu \mathrm{g} / \mathrm{ml}$ lipopolysaccharide (LPS) from Escherichia coli (Sigma) and $50 \mu \mathrm{g} / \mathrm{ml}$ genomic DNA from Vibrio anguillarum.

\section{Chemiluminescence assay}

Respiratory burst activity was measured as the luminoldependent chemiluminescence produced by head-kidney cells (Mulero et al. 2001). This was brought about by adding $100 \mu \mathrm{M}$ luminol (Sigma) and $1 \mu \mathrm{g} / \mathrm{ml}$ phorbol 12-myristate 13-acetate (PMA, Sigma), while the chemiluminescence was recorded every 117 seconds for $1 \mathrm{~h}$ in a FLUOstart luminometer (BGM, LabTechnologies). 
The values reported are the average of octuple readings, expressed as the slope of the reaction curve from 585 to 1170 seconds, from which the apparatus background was subtracted.

\section{Viability assay}

Aliquots of head-kidney cell suspensions incubated with steroid hormones (as described previously) were diluted in $200 \mu \mathrm{l}$ PBS containing $40 \mu \mathrm{g} / \mathrm{ml}$ propidium iodide. The number of red fluorescent cells from triplicate samples was analysed by flow cytometry (FC).

\section{Western blot analysis}

Cell extracts from $5 \times 10^{6}$ cells $(80-100 \mu \mathrm{g}$ per lane) were run in $12 \%$ SDS-PAGE and transferred for $50 \mathrm{~min}$ at $200 \mathrm{~mA}$ to nitrocellulose membranes (BioRad, Barcelona, Spain). The blots were developed using a 1:1000 dilution of anti-sbIL-1 $\beta$ and Immun-Start HPR Substrate kit (BioRad) according to the manufacturer's protocol. Membranes were then stained with a $0 \cdot 1 \%$ Ponceau solution (Sigma) and/or reprobed with a 1:10000 dilution of a monoclonal anti- $\beta$-actin (A5441, Sigma) to confirm a similar protein loading in all lanes. Films were densitometrically scanned and the IL-1 $\beta$ expression relative to $\beta$-actin was determined.

\section{Statistical analysis}

Data were analysed by one-way analysis of variance (ANOVA) and unpaired Student's $t$-test to determine differences between groups. A quantitative study of the FC results was made by using the statistical option of the Lysis Software Package (Becton Dickinson).

\section{Results}

Acidophilic granulocytes are closed to the germ cells in post-spawning testis

Gilthead seabream testis possess a tubular organization and exhibit large variations in size and histological appearance during the reproductive cycle, as has been described in teleosts (reviewed in Pudney 1995). Gilthead seabream spawning (Fig. 1a-e) and post-spawning (Fig. 1f-j) testes were studied. Spawning testes, sampled in December, were classified as early spawning testis (Fig. 1b-e) when tubules formed by spermatogonia, spermatocytes and spermatids cysts and showing few free spermatozoa in a small lumen were observed, and as late spawning (Fig. 1a) when tubules containing spermatocytes and spermatids cysts and a few spermatogonia, which delimited a high lumen full of free spermatozoa, were seen. Post-spawning testes, sampled in February-March, were classified as early post-spawning testes (Fig. 1f) when tubules formed by spermatogonia were mostly open and full of free spermatozoa; as middle post-spawning when tubular organization had broken up, spermatogonia were the main cell type and few spermatozoa remained in some areas of the testis; and as late post-spawning (Fig. 1g-j) when the tubules showed very few remaining spermatozoa, some empty spaces and degenerating cell areas (Fig. 1g).

Cells showing an eccentric nucleus and a strong eosinstained granulated cytoplasm were identified by light microscopy in both spawning and post-spawning testes (Fig. 1f,g). These cells were shown to be acidophilic granulocytes, since they specifically reacted with the G7 (Fig. 1a,b,d,h,i), a monoclonal antibody specific to the gilthead seabream acidophilic granulocytes (Sepulcre et al. 2002). Acidophilic granulocyte location and abundance in the testis are correlated with the reproductive cycle. This cell type was seen to occur isolated or in small clusters in the connective tissue separating the testis from the ovary (Fig. 1a), close to blood vessels located below the tunica albuginea (Fig. 1b,i) or near the deferent duct (Fig. 1d) in spawning (Fig. 1a,b,d) and post-spawning (Fig. 1i) testes. Moreover, they were found in the well-developed connective tissue inside the testis close to the blood vessels, amongst the spermatogonia (Fig. 1f-h) and in the lumen of the tubules between the spermatozoa in the post-spawning testis and around the degenerating areas (Fig. 1g) in late post-spawning testis.

No proliferation of testicular acidophilic granulocytes was observed (Fig. 1d,e), as assayed by the BrdU technique. However, some Sertoli cells, spermatogonia and spermatocytes were found to proliferate in spawning testis (Fig. 1c).

The acidophilic granulocytes of the testis showed the ultrastructural characteristics previously described for gilthead seabream head-kidney (Meseguer et al. 1994) and blood (López-Ruiz et al. 1992) acidophilic granulocytes. Clusters of acidophilic granulocytes were observed in the interstitial areas close to the germ cell cysts, in contact with the peritubular cells of the tubules and surrounded by collagen fibres in the post-spawning stage (Fig. 2). In this stage, free granules, similar to acidophilic granulocyte granules, were also observed close to the acidophilic granulocytes clusters and sometimes near the peritubular cells (Fig. 2). No phagocytosis was observed by testicular acidophilic granulocytes.

\section{Testicular acidophilic granulocytes accumulate intracellular IL-1 $\beta$}

We next investigated whether the acidophilic granulocytes of the testis were able to accumulate intracellular IL-1 $\beta$, since an IL-1-like factor has been found to be a growth factor for spermatogonia in mammals (Söder et al. 1991). The IL-1 $\beta$ immunoreaction (Fig. 1j) was only observed in 

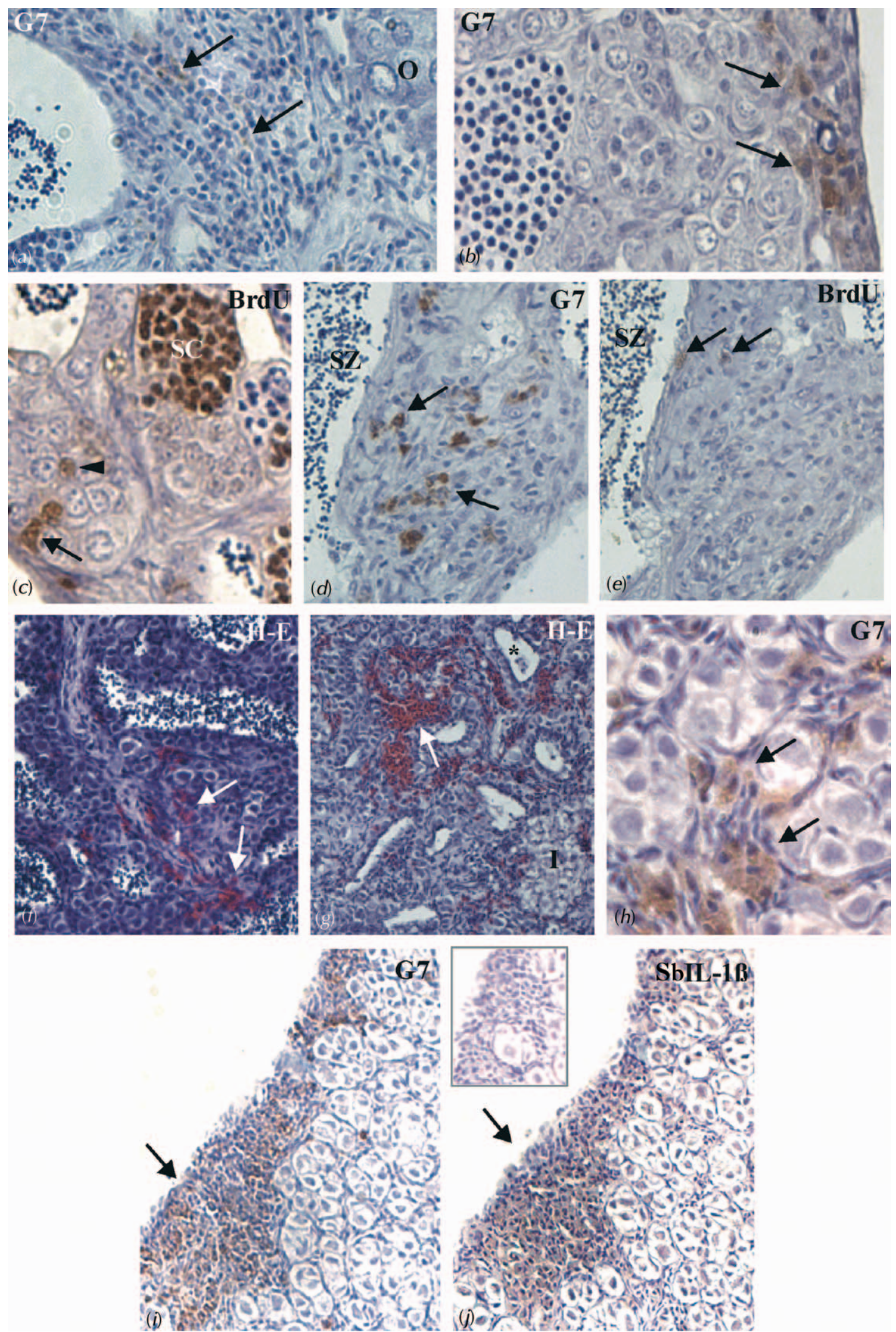

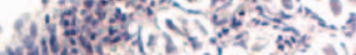
(4)

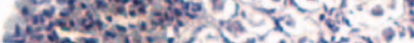

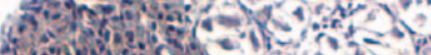

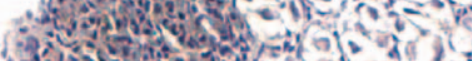
30050 a

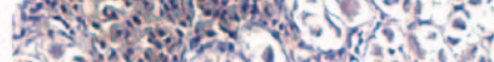
(i) 
the same testicular cells which were immunostained by the G7 antibody (Fig. 1i), the acidophilic granulocytes.

\section{$11-K T$ and $E_{2}$ regulate in vitro the respiratory burst and the intracellular accumulation of IL-1 $\beta$ by acidophilic granulocytes}

The low percentage of testicular acidophilic granulocytes makes them impossible to purify. Therefore, we used head-kidney (the bone marrow equivalent) leucocytes to measure the respiratory burst reaction, which was used as an indicator of the activation of these cells (Ortuño et al. 2000). We found that the in vitro addition of 11-KT resulted in a dose-dependent stimulation $(P<0.0001)$ of the respiratory burst activity after $46 \mathrm{~h}$ of incubation (Fig. 3). In contrast, the addition of $E_{2}$ inhibited this activity at the longest $(46 \mathrm{~h})$ incubation time (Fig. 3). These effects were not due to changes in cell viability after hormone addition, since viability was similar in all the samples after $46 \mathrm{~h}$ of incubation (ranging from $77 \cdot 2 \pm 0.9$ to $80 \cdot 1 \pm 0 \cdot 9)$, as assayed by propidium iodide staining.

These results prompted us to investigate the effect of these two hormones in the intracellular accumulation of IL-1 $\beta$ by head-kidney acidophilic granulocytes (Fig. 4). 11-KT was able to markedly enhance, in a dosedependent manner, the intracellular accumulation of proIL-1 $\beta$ by DNA/LPS-stimulated head-kidney cells at both times assayed (22 and $46 \mathrm{~h}$ ) (Fig. 4a), while $\mathrm{E}_{2}$ produced a significant inhibition of DNA/LPS-stimulated proIL-1 $\beta$ intracellular accumulation by these cells when the highest doses and the shortest incubation time were used (Fig. 4b). Both 11-KT (Fig. 4a) and $\mathrm{E}_{2}$, however, failed to induce the production of IL-1 $\beta$ by resident head-kidney cells which, furthermore, did not produce IL-1 $\beta$ (Fig. 4a). These effects were not due to the different IL-1 $\beta$ secretion rates between control and hormonetreated cells, since these stimuli were not able to induce IL-1 $\beta$ secretion (Pelegrín et al., 2004).

\section{Discussion}

The reproductive cycle of seasonal breeding teleost fish can be divided into four gonadal stages: sexual resting, gametogenic activity, spawning and post-spawning. Throughout this cycle the testis undergoes abrupt morphological changes from being formed by all germinal cell types during spawning to being formed by spermatogonia with some remaining spermatozoa and degenerative cell areas after spawning (Patzner \& Seiwald 1987, Lahnsteiner \& Patzner 1990, Besseau \& Faliex 1994). The gilthead seabream is a protandrous hermaphrodite seasonal breeding sparid. Sparid gonads are well characterized as an ovotestis consisting of a medio-dorsal ovarian area and a lateral-ventral testicular zone, separated by a connective wall. Each gonadal territory functions in a sequential manner (Besseau \& Faliex 1994). Reflecting the protandric pattern, the testicular area becomes functional first, even when an immature ovary adjoins the testicular area. The specimens used for this study were mature males in the spawning and post-spawning stages, some of which showed a small ovarian area.

In mammals, the relationship between the immune and the reproductive systems has been studied for many years (reviewed in Hunt \& Johnson 1999). Different immune cell types, including macrophages, lymphocytes and dendritic cells, have been reported to produce the cytokines which influence gonad activity (Hedger 1997, Hoek et al. 1997, Hedger \& Meinhardt 2003). In turn, specific gonad cell types modify the immune responses inside the reproductive tissues (Hedger 1997). However, little attention has been paid to the immune cell populations involved in the activity of the testis in teleost fish. Some immune cells have been described by light and electron microscopy. Thus, in the gametogenic activity and spawning stages some macrophages have been described in the interstitial tissue of the rainbow trout testis (Loir et al. 1995) whereas in the post-spawning stage a high population of phagocyte cells has been described in several teleost fish (Henderson 1962, Shrestha \& Khanna 1976, Carrillo \& Zanuy 1977, Billard 1986, Scott \& Sumpter 1989, Lahnsteiner \& Patzner 1990, Loir et al. 1995). Moreover, macrophages, granulocytes and lymphocytes have been described in the testis of some sparid fish, although only macrophages have been shown to be phagocytic (Micale et al. 1987, Besseau \& Faliex 1994, Bruslé-Sicard \& Fourcault 1997).

\footnotetext{
Figure 1 (a-e) Sections of the testis of gilthead seabream at the spawning stage. (a and b) Sections immunostained with the G7 antibody. Scattered acidophilic granulocytes (arrows) are seen in the connective tissue limiting the testis (T) from the ovarian (O) area of the gonad (a) and below the tunica albuginea (b). Magnification $\times$ 400. (c) Section immunostained with an antibody against BrdU. Proliferating Sertoli cells (arrow), spermatogonia (arrow head) and spermatocytes (SC) are observed. Magnification $\times 400$. (d and e) Serial sections immunostained with the (d) G7 antibody showing acidophilic granulocytes (arrows) present in the connective tissue close to the deferent duct and (e) immunostained with an antibody against BrdU showing two proliferating cells (arrows). Note that proliferating cells did not react with the G7 antibody; Spermatozoa (SZ). Magnification $\times$ 400. (f-j) Sections of the testis of gilthead seabream at the post-spawning stage. ( $f$ and g) Sections stained with haematoxylin-eosin (H-E). ( $f$ ) Acidophilic granulocytes located between the spermatogonia (arrows) and close to the lumen of the tubules. Magnification $\times 400$. (g) Cluster of acidophilic granulocytes located between the spermatogonia (arrow) and close to the degenerating cells areas. Empty areas (asterisk), degenerating cells areas (I). Magnification $\times 200$. (h) Section immunostained with the G7 antibody, showing a cluster of acidophilic granulocytes (arrows) between the spermatogonial cysts. Magnification $\times 400$. (i-j) Serial sections immunostained with (i) the G7 antibody, showing acidophilic granulocytes located below the tunica albuginea (arrow), and (j) immunostained with the anti-sblL-1 $\beta$ serum showing cells immunopositive for IL-1 $\beta$ (arrow). Note that IL-1 $\beta$ immunostained cells coincide with the G7 immunostained cells. Inset, no immunoreaction was observed, in an adjacent section, when the anti-sblL-1 $\beta$ was omitted. Magnification $\times 400$.
} 

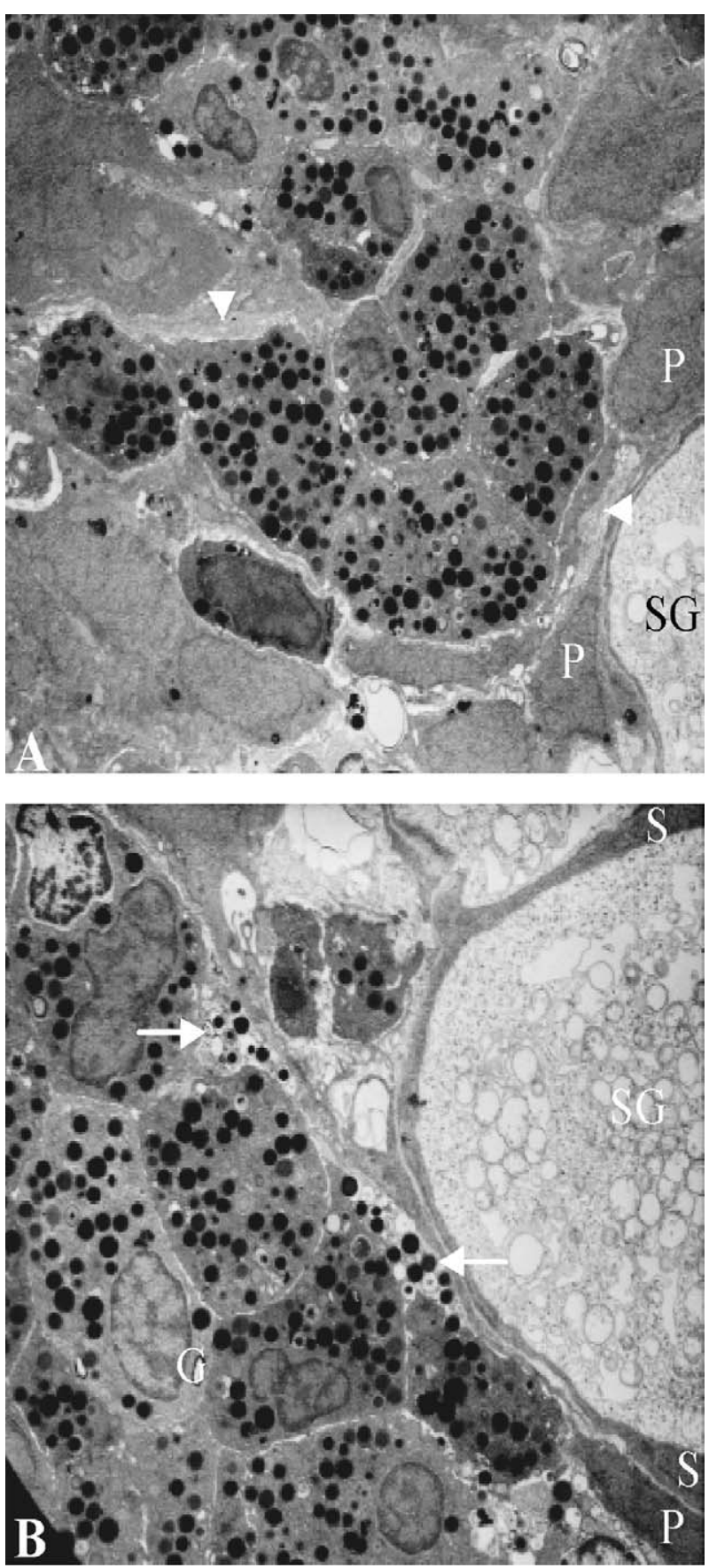

Figure 2 Electron micrographs of acidophilic granulocytes in the gilthead seabream testis at the end of the post-spawning/ beginning of the resting stage. (A) Cluster of acidophilic granulocytes in the collagen lamina (arrow heads) close to a spermatogonia cyst (SG). (B) Cluster of acidophilic granulocytes (G) in the interstitium near a spermatogonia cyst (SG). Note the presence of free granules close to the cyst wall (arrows). (S) Sertoli cell, $(\mathrm{P})$ peritubular cell. Magnification $\times 2500$.
An important difference between mammalian and fish testicular leucocytes is that in mammals the leucocyte infiltration of the testis begins with an inflammation process, whereas in fish the same process is a physiological one which starts at the end of the spawning stage and is presumably regulated by sex hormones.

We describe the existence of a population of acidophilic granulocytes in the testis of gilthead seabream using a monoclonal antibody (G7) that is specific to these cells (Sepulcre et al. 2002). This observation is of particular interest since the morphological and functional characteristics of gilthead seabream acidophilic granulocytes has led to them being considered functionally equivalent to the neutrophils of higher vertebrates. Notably, they are the most numerous phagocyte type in all the immune tissues examined, including peripheral blood, and show high phagocytic activity towards bacteria (Sepulcre et al. 2002).

Although acidophilic granulocytes were present in the connective tissue separating the testis from the ovary, near the deferent duct or close to blood vessels located below the tunica albuginea during spawning and post-spawning stages, they also appeared in the interstitial area and inside the germinal compartment during the post-spawning stage. It had previously been suggested that fish leucocytes may infiltrate the testis at the end of the spawning/ beginning of the post-spawning stages (Besseau \& Faliex 1994, Bruslé-Sicard \& Fourcault 1997) and this seems to be confirmed by this study of seabream testicular acidophilic granulocytes using the BrdU immunohistochemical technique. These data also support the suggestion that the testis is not a haematopoietic organ in teleost fish, as has been described in condrictian fish (Zapata et al. 1996). On the other hand, this distribution pattern of acidophilic granulocytes during the reproductive cycle would suggest a possible role for them in the phagocytosis of degenerative cells in the post-spawning period, since residual spermatozoa and other germ cells are eliminated from the testis during this stage, as has been described in Salaria pavo (Lahnsteiner \& Patzner 1990) and in Lithognathus mormyrus (Besseau \& Faliex 1994). Nevertheless, the electron microscopy study led us to discard this hypothesis, although gilthead seabream head-kidney acidophilic granulocytes have high phagocytic capacity against the bacterium $V$. anguillarum (Sepulcre et al. 2002).

The presence of free granules, similar to those found in the cytoplasm of acidophilic granulocytes, in the interstitial areas of the testis close to this cell type during the post-spawning stage is noticeable, as had been described previously in this species (Bruslé-Sicard \& Fourcault 1997). However, free granules have not been observed in the testis of the protandric sparid, Lithognathus mormyrus (Besseau \& Faliex 1994). The role, if any, of these free granules in the interstitial compartment of the testis needs further investigation.

The most important finding of this study is that acidophilic granulocytes from the testis accumulate intracellular 


\section{$0.1 \mathrm{ng} / \mathrm{ml} \square 0.5 \mathrm{ng} / \mathrm{ml} \quad \bigotimes 1 \mathrm{ng} / \mathrm{ml} \quad \not{ } 5 \mathrm{ng} / \mathrm{ml}$}

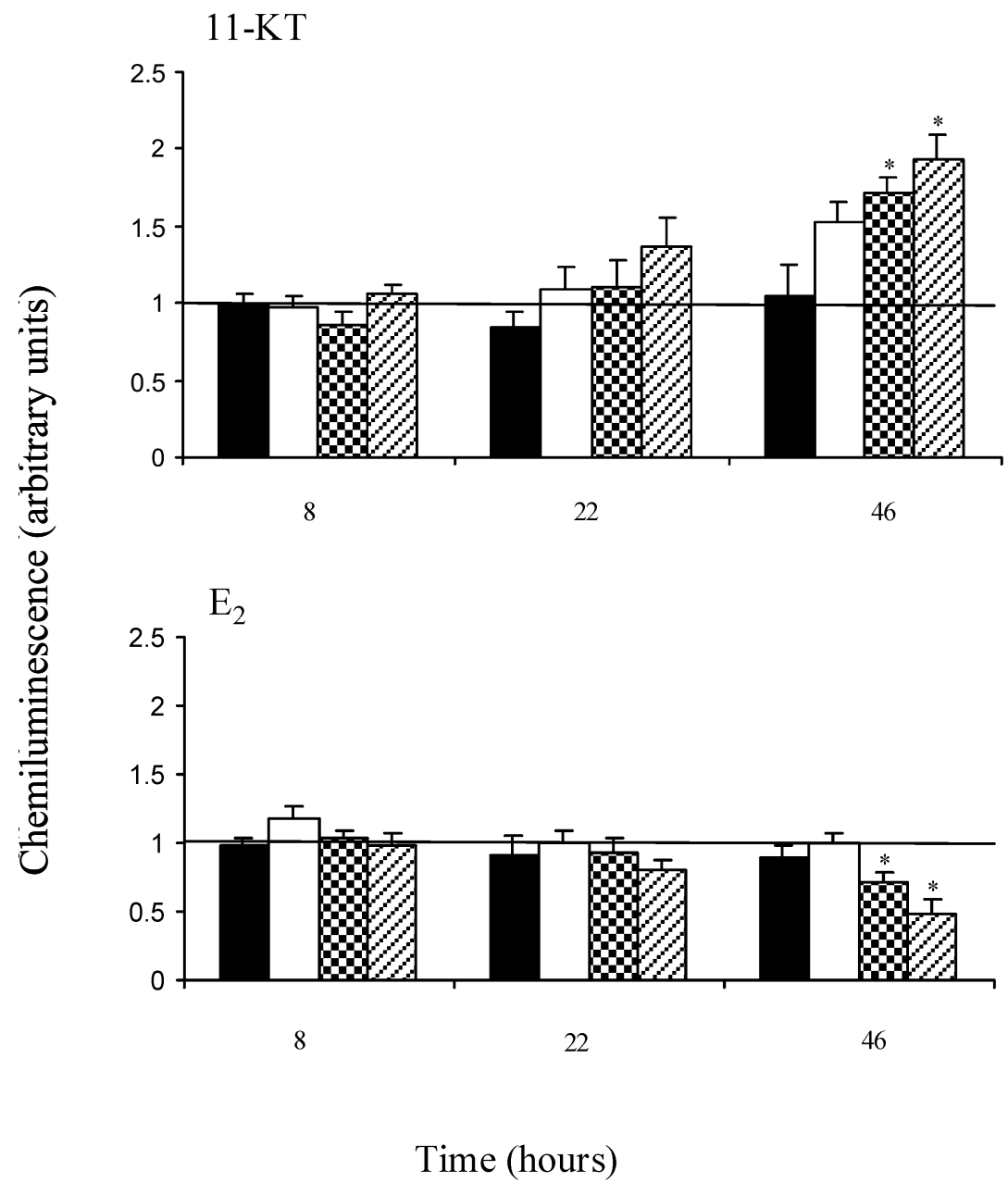

Figure 3 Respiratory burst activity of head-kidney phagocytes stimulated for the indicated times with $0 \cdot 1,0 \cdot 5,1$ and $5 \mathrm{ng} / \mathrm{ml} 11-\mathrm{KT}$ (upper panel) or $E_{2}$ (lower panel). Data represent the mean \pm S.E. of octuple cultures. Horizontal line represents the control value (cells incubated with hormones). ${ }^{*} P<0.05$ significant difference between control and hormone-treated cells.

IL-1 $\beta$. It remains to be elucidated, however, whether this intracellular accumulation of IL-1 $\beta$ by testicular acidophilic granulocytes represents the production of the cytokine by the cells or its uptake. In mammals, Sertoli cells, Leydig cells and macrophages produce both IL-1 $\alpha$ and IL-1 $\beta$ in the testis (Hedger 1997, Hoek et al. 1997, Hedger \& Meinhardt 2003). To date an IL-1 $\alpha$ homologue has not been described in teleost fish, and it is quite likely that it does not exist, since a BLAST search against the Fugu rubripes genomic database, which covers $\sim 100 \%$ of the genome of this teleost species, failed to retrieve an IL-1 $\alpha$ gene homologue.
In mammals, the role played by IL- 1 in the testis is controversial. Some studies have found that both IL-1 $\alpha$ and IL-1 $\beta$ are potent growth factors for spermatogonia and Leydig cells (Pöllänen et al. 1989, Parvinen et al. 1991, Khan et al. 1992) and inhibitors of Leydig cell androgen production (Calkins et al. 1988, 1990). However, Cohen and Pollard (1998) have reported that mice lacking a functional type I IL-1 receptor, the only IL-1 receptor subtype capable of IL-1-induced signal transduction, are fertile and have normal testosterone levels. Although little is known about the effect of IL-1 in the fish testis, an heterologous recombinant cytokine, murine IL- $1 \beta$, has 
(a) LPS/DNA

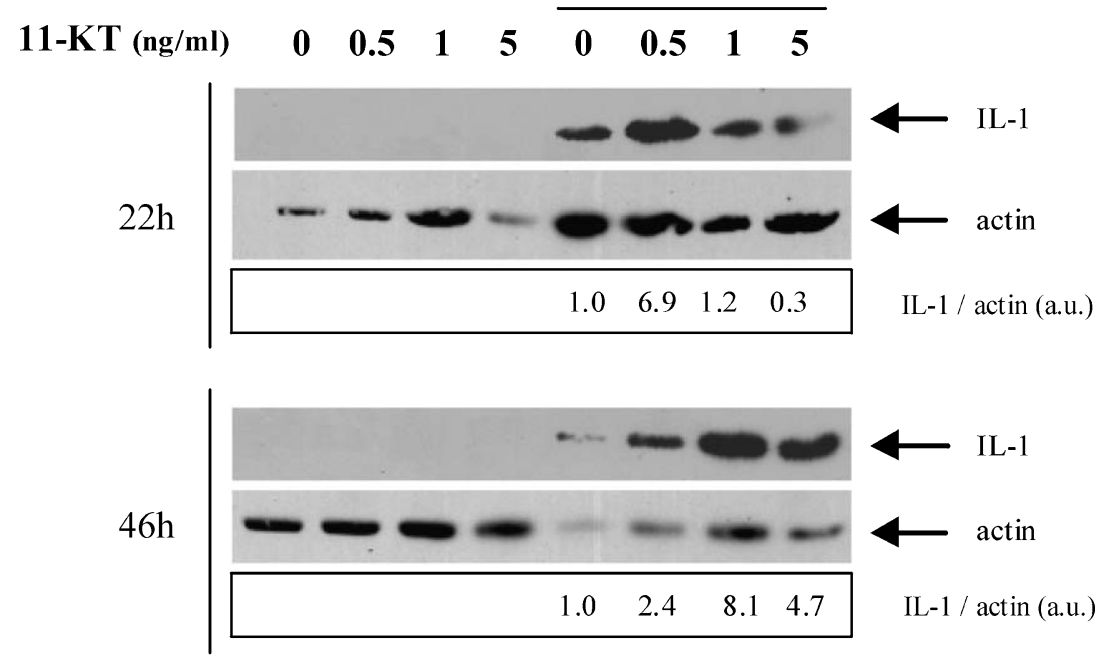

(b)

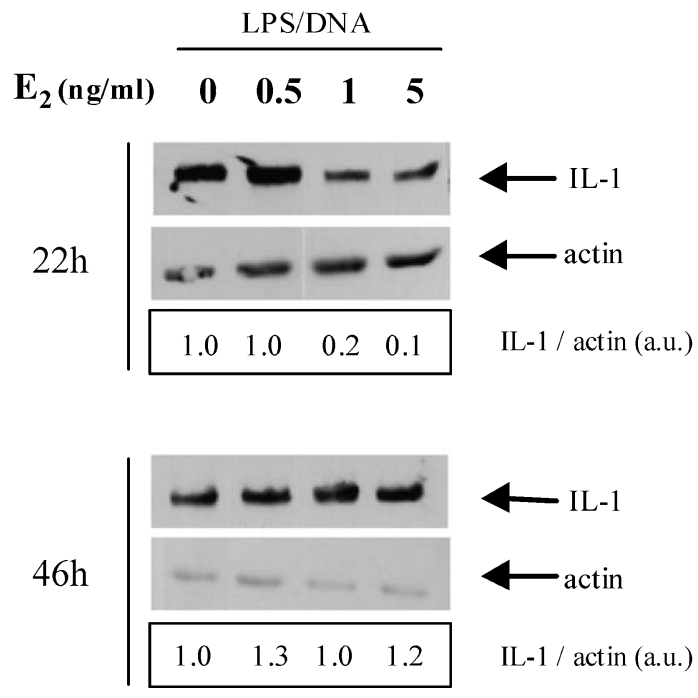

Figure $4 \mathrm{IL}-1 \beta$ immunoblot from head-kidney phagocytes pre-treated with $0 \cdot 5,1$ and $5 \mathrm{ng} / \mathrm{ml} 11-\mathrm{KT}$ (a) or $\mathrm{E}_{2}$ (b) for 6 or $30 \mathrm{~h}$ and then stimulated for $16 \mathrm{~h}$ with $10 \mu \mathrm{g} / \mathrm{ml} \mathrm{LPS}$ from E. coli and $50 \mu \mathrm{g} / \mathrm{ml}$ genomic DNA from V. anguillarum. Membranes were probed with anti-sblL-1 $\beta$ antiserum and then reprobed with a monoclonal anti- $\beta$-actin. The IL-1 $\beta$ expression relative to $\beta$-actin was calculated. The results are representative of three independent experiments.

been suggested to inhibit basal and human chorionic gonadotrophin (hCG)-stimulated testosterone production in the goldfish testis (Lister \& Van der Kraak 2002). Taking all this into account, it is tempting to speculate that testicular IL-1 $\beta$ might act as a germ cell growth factor and/or a steroidogenesis modulator in fish. Whatever the case, our data show that IL-1 $\beta$ is intracellularly accumu- lated by acidophilic granulocytes in the gilthead seabream testis, but do not rule out the possibility that other testicular cell types, such as Sertoli cells, Leydig cells or even macrophages produce this cytokine at lower levels, undetectable by immunocytochemistry, as has already been described in mammals (Kern et al. 1995, Cudicini et al. 1997, Hedger \& Meinhardt 2003). 
11-KT and $\mathrm{E}_{2}$ are the main steroid hormones produced by the fish gonads and in several male teleost fish 11-KT peaks during the pre-spawning stage and $\mathrm{E}_{2}$ during the spawning stage (Rosenblum et al. 1987, Borg 1994, Weltzien et al. 2002). Moreover, $\mathrm{E}_{2}$ promotes spermatogonial stem cell renewal in the Japanese eel (Miura et al. 1999). We investigated the capacity of these hormones to activate in vitro head-kidney acidophilic granulocytes. It was not possible to take a similar approach with acidophilic granulocytes from the testis because these cells are very scarce in this organ. Moreover, the head-kidney is the main source of acidophilic granulocytes in teleost fish (Zapata et al. 1996) reaching $85 \%$ of phagocytic cells in gilthead seabream (Sepulcre et al. 2002), which suggests that the infiltrated acidophilic granulocytes found in gilthead seabream testes come from the head-kidney. Our results show that 1 and $5 \mathrm{ng} / \mathrm{ml} 11-\mathrm{KT}$ were able to activate the respiratory burst of head-kidney acidophilic granulocytes after $46 \mathrm{~h}$ incubation. In contrast, $\mathrm{E}_{2}$ inhibited this activity at similar incubation times and concentrations. Interestingly, these concentrations of 11-KT correspond to the physiological levels reached in some stages of the reproductive cycles of teleost fish (Rosenblum et al. 1987, Gazola \& Borella 1997, Weltzien et al. 2002) while $\mathrm{E}_{2}$ concentrations, which inhibited activation, were slightly higher in the males and close to the female $\mathrm{E}_{2}$ concentrations reported previously in some teleost species (Rosenblum et al. 1987, Miura et al. 1999, Lone et al. 2001). Moreover, 11-KT enhanced while $E_{2}$ inhibited proIL-1 $\beta$ intracellular accumulation by LPS/DNAstimulated head-kidney acidophilic granulocytes in a dosedependent manner. These effects might suggest a role for these hormones in the regulation of IL-1 $\beta$ intracellular accumulation by acidophilic granulocytes of the testis, although other factors are probably involved in this process since these two hormones on their own failed to promote the intracellular accumulation of IL-1 $\beta$ in resident headkidney acidophilic granulocytes. Although both respiratory burst and IL-1 $\beta$ production are responses of the phagocytic cells, we cannot rule out the possibility that $11-\mathrm{KT}$ and $\mathrm{E}_{2}$ may also affect lymphocytes present in head-kidney cell suspensions, which, in turn, might modulate the accumulation of IL-1 $\beta$ by acidophilic granulocytes.

To conclude, the data obtained in this study demonstrate that testicular acidophilic granulocytes produce IL-1 $\beta$ and suggest that they are not actively involved in the phagocytosis of degenerating post-spawning cells. The production of IL- $1 \beta$ by this cell population may be regulated throughout the reproductive cycle by sexual hormone levels. It is not possible to exclude, however, other hormones or factors that might modulate testicular acidophilic granulocytes nor the roles performed by other immune cells inside the testis. Our data point to the need for further research to complete our knowledge about the complex interactions between the immune and the reproductive systems in teleost fish.

\section{Acknowledgements}

We thank the 'Servicio de Apoyo a las Ciencias Experimentales' S.A.C.E. of the University of Murcia for their assistance with cell culture and electron microscopy.

\section{Funding}

This work was supported by Fundación Séneca, Coordination Centre for Research (grant PI-51/00782/FS/01) and Spanish Ministry of Education, Culture and Sports (fellowship to E C-P). There is no conflict of interest that would prejudice the impartiality of this paper.

\section{References}

Besseau L \& Faliex E 1994 Resorption of unemitted gametes in Lithognathus mormyrus (Sparidae, Teleostei): a possible synergic action of somatic and immune cells. Cell and Tissue Research 276 123-132.

Billard R 1986 Spermatogenesis and spermatology of some teleost fish species. Reproduction, Nutrition, Development 26 877-920.

Borg B 1994 Androgens in teleost fishes. Comparative Biochemistry and Physiology 109C 219-245.

Bruslé-Sicard S \& Fourcault B 1997 Recognition of sex-inverting protandric Sparus aurata: ultrastructural aspects. Journal of Fish Biology 50 1094-1103.

Calkins JH, Sigel MM, Nankin HR \& Lin T 1988 Interleukin-1 inhibits Leydig cell steroidogenesis in primary culture. Endocrinology 123 1605-1610.

Calkins JH, Guo H, Sigel MM \& Lin T 1990 Differential effects of recombinant interleukin-1 alpha and beta on Leydig cell function. Biochemical and Biophysical Research Communications 167 548-553.

Carrillo M \& Zanuy S 1977 Quelques observations sur le testicule chez Spicara chryselis. Investigaciones Pesqueras 41 121-146.

Cohen PE \& Pollard JW 1998 Normal sexual function in male mice lacking a functional type I interleukin-1 (IL-1) receptor. Endocrinology 139 815-818.

Cudicini C, Lejeune H, Gomez E, Bosmans E, Ballet F, Saez J \& Jégou B 1997 Human Leydig cells and Sertoli cells are producers of interleukins-1 and -6. Journal of Clinical Endocrinology and Metabolism 82 1426-1433.

D'Ancona U 1941 Ulteriori osservazioni sull'ermafroditismo e il differenziamento sessuale dell'orata (Sparus auratus L.) (Completamento della ricerche della Dott. A. Pasquali). Pubblicazioni della Stazione Zoologica di Napoli 18 313-336.

Gazola R \& Borella MI 1997 Plasma testosterone and 11-ketotestosterone levels of male pacu Piaractus mesopotamicus (Cypriniformes, Characidae). Brazilian Journal of Medical and Biological Research 30 1485-1487.

Hedger MP 1997 Testicular leucocytes: what are they doing? Reviews of Reproduction 2 38-47.

Hedger MP \& Meinhardt A 2003 Cytokines and the immunetesticular axis. Journal of Reproductive Immunology 58 1-26.

Henderson NE 1962 The annual cycle in the testis of eastern brook trout Salvelinus fontinalis (Mitchell). Canadian Journal of Zoology 40 631-641.

Hoek A, Allaerts W, Leenen PJ, Schoemaker J \& Drexhage HA 1997 Dendritic cells and macrophages in the pituitary and the gonads. Evidence for their role in the fine regulation of the reproductive endocrine response. European Journal of Endocrinology 136 8-24.

Hunt JS \& Johnson PM 1999 Immunology of Reproduction. In Encyclopedia of Reproduction, vol 2, pp 798-806. Eds E Knobil \& JD Neil. New York: Academic Press. 
Kern S, Robertson SA, Mau VJ \& Maddocks S 1995 Cytokine secretion by macrophages in the rat testis. Biology of Reproduction $\mathbf{5 3}$ 1407-1416.

Khan SA, Khan SJ \& Dorrington JH 1992 Interleukin-1 stimulates deoxyribonucleic acid synthesis in immature rat Leydig cells in vitro. Endocrinology 131 1853-1857.

Lahnsteiner F \& Patzner RA 1990 The mode of male germ cell renewal and ultrastructure of early spermatogenesis in Salaria (=Blennius) pavo (Teleostei: Blenniidae). Zoologischer Anzeiger 224 129-139.

Lasserre G 1972 Le coefficient de condition chez la daurade Sparus auratus L. 1758 de la région de Sète en 1971-1972. Travaux du Laboratoire de Biologie Halientique, Université de Rennes 6 141-150.

Lister A \& Van der Kraak G 2002 Modulation of goldfish testicular testosterone production in vitro by tumor necrosis factor alpha, interleukin-1 beta, and macrophage conditioned media. Journal of Experimental Zoology 292 477-486.

Loir M, Sourdaine P, Mendis-Handagama SM \& Jégou B 1995 Cell-cell interactions in the testis of teleosts and elasmobranchs. Microscopic Research Technique 32 533-552.

Lone KP, Al-Ablani S \& Al-Yaqout A 2001 Steroid hormone profiles and correlative gonadal histological changes during natural sex reversal of sobaity kept in tanks and sea-cages. Journal of Fish Biology 58 305-324.

López-Ruiz A, Esteban MA \& Meseguer J 1992 Blood cells of the gilthead seabream (Sparus aurata L.). Light and electron microscopic studies. Anatomical Record 234 161-171.

Meseguer J, López-Ruiz A \& Esteban MA 1994 Cytochemical characterization of leucocytes from the seawater teleost, gilthead seabream (Sparus aurata L.). Histochemistry 102 37-44.

Micale V, Perdichizzi F \& Santangelo G 1987 The gonadal cycle of captive white bream, Diplodus sargus (L.). Journal of Fish Biology 31 435-440.

Miura T, Miura C, Ohta T, Nader MR, Todo T \& Yamauchi K 1999 Estradiol-17 $\beta$ stimulates the renewal of spermatogonial stem cells in males. Biochemical and Biophysical Research Communications 264 230-234.

Mulero V, Pelegrín P, Sepulcre MP, Muñoz J \& Meseguer J 2001 A fish cell surface receptor defined by a mAb mediates leukocyte aggregation and deactivation. Developmental and Comparative Immunology 25 619-627.

Ortuño J, Esteban MA \& Meseguer J 2000 Kinetics of hydrogen peroxide production during in vitro respiratory burst of seabream (Sparus aurata L.) head-kidney leucocytes, as measured by a flow cytometric method. Fish and Shellfish Immunology 10 725-729.

Parvinen M, Söder O, Mali P, Froysa B \& Ritzen EM 1991 In vitro stimulation of stage-specific deoxyribonucleic acid synthesis in rat seminiferous tubule segments by interleukin-1 alpha. Endocrinology 129 1614-1620

Pasquali A 1941 Contributo allo studio dell'ermafroditismo e del differenziamento della gonade nell'orata (Sparus auratus L.). Publicazioni della Stazione Zoologica di Napoli 18 282-312.
Patzner RA \& Seiwald M 1987 The reproduction of Blennius pavo (Teleostei, Blenniidae). VI. Testicular cycle. Zoologischer Anzeiger 219 265-273.

Pelegrín P, Chaves-Pozo E, Mulero V \& Meseguer J 2004 Production and mechanism of secretion of fish interleukin-1 $\beta$. Developmental and Comparative Immunology (In Press).

Pöllä nen P, Söder O \& Parvinen M 1989 Interleukin-1 alpha stimulation of spermatogonial proliferation in vivo. Reproduction, Fertility, and Development 1 85-87.

Pudney J 1995 Spermatogenesis in nonmammalian vertebrates. Microscopic Research Technique 32 459-497.

Robertson SA 1999 Cytokines. In Encyclopedia of Reproduction, vol 1, pp 809-822. Eds E Knobil \& JD Neil. New York: Academic Press.

Rosenblum PM, Pudney J \& Callard IP 1987 Gonadal morphology, enzyme histochemistry and plasma steroid levels during the annual reproductive cycle of male and female brown bullhead catfish, Ictalurus nebulosus Lesueur. Journal of Fish Biology 31 325-341.

Scott AP \& Sumpter JP 1989 Seasonal variations in testicular germ cell stages and in plasma concentrations of sex steroids in male rainbow trout (Salmo gairdneri) maturing at 2 years old. General and Comparative Endocrinology 73 46-58.

Sepulcre MP, Pelegrín P, Mulero V \& Meseguer J 2002 Characterisation of gilthead seabream acidophilic granulocytes by a monoclonal antibody unequivocally points to their involvement in fish phagocytic response. Cell and Tissue Research 308 97-102.

Shrestha TK \& Khanna SS 1976 Histology and seasonal changes in the testes of a hill-stream fish Schizothorax plagiostomus. Zeitschrift fur Mikroskopisch-Anatomische Forschung 90 749-761.

Söder O, Syed V, Callard GV, Toppari J, Pöllänen P, Parvinen M, Froysa B \& Ritzen EM 1991 Production and secretion of an interleukin-1-like factor is stage-dependent and correlates with spermatogonial DNA synthesis in the rat seminiferous epithelium. International Journal of Andrology 14 223-231.

Sternberger LA (ed) 1986 Immunocytochemistry, edn 3. New York: Wiley.

Tuo W, Bazer FW \& Brown WC 1999 Lymphokines. In Encyclopedia of Reproduction, vol 2, pp 1102-1118. Eds E Knobil \& JD Neil. New York: Academic Press.

Weltzien FA, Taranger GL, Karlsen Ø \& Norberg B 2002 Spermatogenesis and related plasma androgen levels in Atlantic halibut (Hippoglossus hippoglossus L.). Comparative Biochemistry and Physiology. Part A, Molecular and Integrative Physiology 132 567-575.

Zapata AG, Chibá A \& Varas A 1996 Cells and tissues of the immune system of fish. In The Fish Immune System. Organism, Pathogen, and Environment, pp 1-62. Eds G Iwama \& T Nakanishi. San Diego: Academic Press.

Received in final form 15 July 2003

Accepted 7 August 2003

Made available online as an

Accepted Preprint 15 August 2003 